\title{
THE INFLUENCE SOCIO-DRAMA METHOD TOWARD STUDENTS' SPEAKING SKILL AT TEN GRADE OF SMKN 4 BATAM IN THE ACADEMIC YEAR 2017/2018
}

\author{
Icha Wany Pangaribuan ${ }^{1}$, Juwita Boneka Sinaga ${ }^{2}$ \\ English Department, University of Riau Kepulauan, Batam, Indonesia \\ Ichawanypangaribuan@gmail.com 1;Juwitaboneka@gmail.com2
}

\begin{abstract}
The research aims of this research was carried out to find the influence of using socio-drama method in teaching speaking for ten grade of junior high school at SMKN 4 Batam whether there is significance different in speaking achievement of the students who are taught using a socio-drama and those who are taught without socio-drama. The subjects of the study were 76 students. The method uses in this study was quasi experimental study with Non Equivalent Control Group design. The researchers divided two classes into an experimental class and a control class. Before the treatment, the researcher did a pre-test in both classes. Moreover, the researcher taught speaking by a socio-drama method in the experimental class. The last, the researchers conducted a post-test in both. After that, she calculated independent sample t-test to analyze the data. Value of the significant was 0.000 and significant level 5\% was 0.05. As the result, the value of significant was lower than significant level. It can be concluded that the using of socio-drama method able to encourage the students to affective in teaching speaking and the hypothesis tested in this study was accepted.
\end{abstract}

Keywords: Speaking skill, Socio-drama Method.

\section{INTRODUCTION}

In Indonesia, English is taught as a foreign language based on the guidance incurriculum which is always provided with syllabus. The curriculum that progressess now what is called a curriculum 2013. In language, there are four language skills to be taught to the students, they are: speaking, listening, reading and writing. According to Ur (1991:120) there four skills are all important. However, all of four skill speaking seems intuitively the most important.

According to Cameron (2001:40) states speaking is the active use of language to express meaning so that other people can make sense of them, therefore, the label of "receptive" and "productive" uses of language can be applied to speaking respectively". As human beings, especially as social creatures have a need to make meaning of their surroundings by communicating each other. They have a need to express their thoughts, opinions, or feelings in order to be accepted in social life. Speaking does not only make sound by the speech organs but ideas and emotions.

To improve speaking ability, the role of teaching speaking in Indonesia is very important in order to achieve communicative competence. Therefore, not only for vocational high school 
but also for university level, Speaking becomes one of the goals of teaching and learning in Indonesia. In order to develop learners' communicative ability, the teacher needs to create a scenario to teach the target language enthusiastically, actively, and interestingly. Besides, the method that used by the teacher should be interesting because the teacher should motivate the students to speak English confidently and to make the students interest in speaking English.

Students need to use appropriate method in learning speaking skill. The researcher interested in applying one of the teaching English especially in speaking skill which is named socio-drama method. Socio-drama method able to help students to speak with expression by group drama. The Socio-drama method is a method of teaching where the teacher gives the opportunity to students to perform a certain role, such as that contained in the social life of the community. Using a socio-drama method in teaching speaking is one of the ways to build the students' interest, motivation and fluency in speaking English by creating interaction in the class and ordering students to imagine themselves in a situation like in the real world.

In the fact, teaching student to speaking is not easy. There are many problems in teaching speaking for vocational high school. First, they might not have motivation in speaking subject. They did not feel interesting in speaking. Second, the students lack vocabularies. Third, they rarely practiced speaking and the last, they were not confident and felt shy to speak in front of class. The researcher limited the study on "The Influence of Socio-drama Method toward Students' Speaking Skill at Ten Grade of SMKN 4 Batam in The Academic Year 2017/2018”.

According to Cameron (2001:40) states "Speaking is the active use of language toexpress meaning so that other people can make sense of them, therefore, the label of "receptive" and "productive" uses of language can be applied to speaking respectively". It can be synthesized that speaking is the way to express ideas, opinions, or feelings with others by using words or sounds in delivering message. As human beings, especially as social creatures have a need to make meaning of their surroundings by communicating each other. They have a need to express their thoughts, opinions, or feelings in order to be accepted in social life. Speaking does not only make sound by the speech organs but ideas and emotions. Therefore, in formal environment between teachers and students have to always interact to make communication. Because of in fact, most of our daily communication remain interactional. It can interact in language is essential. 
There are four components areas of speaking skill which each area plays as its function and there are also some factors affect the effectiveness of speaking and should be in the teaching of speaking. Speaking is a complex skill that using different ability to assess it. According to McKay (2006:292) stated "they can be written to reflect the construct being assessed and to reflect the young learner curriculum". Based on the criterion, Penny McKay for scoring speaking, there are Comprehension, Fluency, Vocabulary, Pronunciation, and Grammar for describes performance and to see progress of the students.

According to Djamarah (2010:88) "Socio-drama method is the way to teach which give chance for student to play the role in social life." It's mean that the teacher gives the opportunity to students to perform a certain role, such as that contained in the social life of the society. Socio-drama Method is a method of learning that involves the interaction students about a topic where students play a role or dramatize the behavior in accordance with the character played by students, in social relations between humans.

There are some instructions for being able to apply this method. The simulation (sociodrama method) steps according to Sanjaya (2006:161-162) are: Preparation, Implementation and Closing. In preparation teacher gives an overview of the problem in the situation to be simulated and teacher determines the players to be involved in the simulations, the roles that the cast will have to play, and the time it takes. In Implementation teachers should provide assistance to the cast who gets into trouble and simulation should be stopped at peak time. This is intended to encourage students to think in solving a problem that is being simulated. Last in closing discussed both simulated and simulated story material, teachers should encourage students to provide criticism and responses to the simulation execution process and formulate conclusions.

\section{METHODOLOGY}

The research used quasi experimental study with Non Equivalent Control Group design as design. According to Sugiyono (2012:116) "the Non Equivalent Control Group design similar to preteset-posttest group design but there is differences in the experiment group nor control group that not selected by randomly". Furthermore, this research used two classes as sample. 
The first class function as experimental class (A) treat by used Socio-drama method and second was control class (B) which treat by used pair work method. All of the ten grade students of SMKN 4 Batam in the academic year 2017/2018 were the target population of this study. The sample was taken by purposive sampling. Furthermore, this research used two classes as sample X KA and X KI 3. The number of the students used as the sample in this research is 76 students.

The researchers used a speaking test as the instrument for this study. To know students speaking skill, the researcher tested students with group drama directly. The researchers give situation to the students in the pre-test and the post-test at the first meeting and the last meeting. In this research, the researchers used content validity of the test. To make the test have a high degree of validity, the reserchers constructed the test based on English Syllabus of Vocational High School. In this research, the researchers used inter rater reliability to score the same students' performance with the same rating scale. The researchers divides the score into five components based on Penny McKay, those are Comprehension, Fluency, Vocabulary, Pronunciation, and Grammar. The data were analyzed based on the result of the speaking test. After collected the data, it was analyzed by using quantitative data that consist of normality test, homogenity test and hypothesis test thought SPSS (Statistical Package Social Science) 20 program for windows.

\section{Normality of the test}

Normality testing was analyzed toward two of the data group: speaking skill data of experimental class and speaking skill data of control class. The testing was analyzed by using liliefors with SPSS 20. The speaking skill score was calculated by using the formula:

$$
x-x
$$

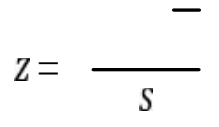

The normality test, the researcher got two kinds of value; if value significant $>\alpha: 0.05$ (significant level) then the data is normally distributed. 
Table 1. The Summary of Normality Testing

\begin{tabular}{ccccc}
\hline Test & Class & $\begin{array}{c}\text { Significant } \\
\text { level }\end{array}$ & $\begin{array}{c}\text { Significant } \\
\text { Value }\end{array}$ & Conclusion \\
\hline Pre test & Control & 0.05 & 186 & Normal \\
\cline { 2 - 5 } & Experiment & 0.05 & 136 & Normal \\
\hline \multirow{2}{*}{ Post test } & Control & 0.05 & 116 & Normal \\
\cline { 2 - 5 } & Experiment & 0.05 & 115 & Normal
\end{tabular}

In pre-test control class, the significant value of 0,186 . Significant data normality analysis result obtained from the Control class was $\alpha: 0.05(0.186>0.05)$. In pre-test experimental class, the significant value of 0,136 . Significant data normality analysis result obtained from the experimental class of $\alpha$ : 0.05 (0.136.>0.05). In post-test control class, the significant value of 0,116 . Significant data normality analysis result obtained from the control class of $\alpha$ : 0.05 (0.116.>0.05). In post-test experimental class, the significant value of 0,115 . Significant data normality analysis result obtained from the experimental class of $\alpha: 0.05$ (0.115.>0.05). The researcher can conclude that all the data is normally distributed.

\section{Homogenity of the test}

In this research, the homogenity was tasted to know whether each groups had the same variance or not. It was tasted by using Fisher test / F-test. If value significant $>\alpha$ : 0.05 (significant level), Sig. Value < Sig. Level (0/05), it showed the classes had homogeneity.

Table 2. The Summary of homogenity Testing

\begin{tabular}{cccc}
\hline Variable & Significat level & Significat value & Conclusion \\
\hline Pre test & 0.05 & 712 & Homogeneous \\
\hline Post test & 0.05 & 101 & Homogeneous \\
\hline
\end{tabular}

Table homogenity test data above, obtained a significant value in pre-test was 0.712 $(0.712>0.05)$ and significant value in post-test was $0,101(0.101>0.05)$. Both of the value significant was greater than 0.05 . It means that both of the variances were homogeneous.

\section{T test}

In this study, $\mathrm{t}$ test calculations by independent sample $\mathrm{t}$ test were doing using SPSS 20 program. The conclusion of t-test between mean score of post-test of experimental and control class is as follow: 
Table 3. The Summary of Indepedent sample t-test

\begin{tabular}{|c|c|c|c|c|c|c|c|c|c|c|}
\hline \multicolumn{11}{|c|}{ Independent Samples Test } \\
\hline & & \multicolumn{2}{|c|}{$\begin{array}{l}\text { Levene's Test } \\
\text { for Equality of } \\
\text { Variances }\end{array}$} & \multicolumn{7}{|c|}{ t-test for Equality of Means } \\
\hline & & \multirow[t]{2}{*}{$\mathrm{F}$} & \multirow[t]{2}{*}{ Sig. } & \multirow[t]{2}{*}{$\mathrm{T}$} & \multirow[t]{2}{*}{ df } & \multirow[t]{2}{*}{$\begin{array}{l}\text { Sig. } \\
(2- \\
\text { tailed } \\
)\end{array}$} & \multirow[t]{2}{*}{$\begin{array}{l}\text { Mean } \\
\text { Differ } \\
\text { ence }\end{array}$} & \multirow[t]{2}{*}{$\begin{array}{l}\text { Std. } \\
\text { Error } \\
\text { Differ } \\
\text { Ence }\end{array}$} & \multicolumn{2}{|c|}{$\begin{array}{l}95 \% \\
\text { Confidence } \\
\text { Interval of the } \\
\text { Difference }\end{array}$} \\
\hline & & & & & & & & & Lower & Upper \\
\hline \multirow{2}{*}{$\begin{array}{l}\text { Result of } \\
\text { Independe } \\
\text { nt sample t } \\
\text { test }\end{array}$} & $\begin{array}{l}\text { Equal } \\
\text { variances } \\
\text { assumed }\end{array}$ & 2,759 &, 101 & $\begin{array}{l}- \\
8,3 \\
87\end{array}$ & 74 &, 000 & $\begin{array}{l}- \\
8,052 \\
63\end{array}$ & $\begin{array}{l}, 9601 \\
0\end{array}$ & $\begin{array}{l}- \\
9,965 \\
68\end{array}$ & $\begin{array}{l}- \\
6,139 \\
58\end{array}$ \\
\hline & $\begin{array}{l}\text { Equal } \\
\text { variances } \\
\text { not } \\
\text { assumed }\end{array}$ & & & $\begin{array}{l}- \\
8,3 \\
87\end{array}$ & $\begin{array}{l}72, \\
08 \\
3\end{array}$ &, 000 & $\begin{array}{l}- \\
8,052 \\
63\end{array}$ & $\begin{array}{l}, 9601 \\
0\end{array}$ & $\begin{array}{l}- \\
9,966 \\
53\end{array}$ & $\begin{array}{l}- \\
6,138 \\
74\end{array}$ \\
\hline
\end{tabular}

The results of speaking test using the method of socio-drama and pair work methods have significant $=0,000$ and the result of hypothesis test of two pair above, that sig $=0.000$. Its means $0.000<0.05$ then $\mathrm{H}_{0}$ is rejected. Based on calculation significant value, it means there is significant effect of socio-drama method. It means the writer hypothesis $H_{a}$ is accepted.

\section{DISCUSSION}

Based on the result above, the calculation of independent sample t-test for two class shows that significant value is low than significant level $(\alpha=0.05)$ (sig.value $<\alpha=0.05$ ), sig.value $=0.000$ and sig. level $(\alpha)=0.05(5 \%)$. Therefore, means there is difference of the influence between socio-drama method and pair work method to towards student's speaking skill at 10th grade in SMKN 4 Batam in academic 2016/2017. It means the writer hypothesis $\mathrm{Ha}$ (there is a significant difference in teaching speaking by using socio-drama method to the ten grade of SMKN 4 Batam) is accepted. This result has answered the research questions that the use of socio-drama method in teaching speaking is quite effective. From explanation above, the writer concluded that socio-drama method gave significant effect towards students' speaking skill. It can be proven by Alternative Hypothesis is accepted and Null Hypothesis is rejected. The score from post- test is higher than pre-test. Therefore, socio-drama method is appropriate to be used in teaching speaking. 


\section{REFERENCES}

Ur, P. (1991). A Course a Languge Teaching Practice And Theory. United Kingdom:

Cambridge University Press.

Cameron, L. (2001). Teaching languages to Young Learners. United Kingdom: Cambridge University Press.

McKay, P. (2006). Assessing Young Language Learners. United Kingdom: Cambridge University Press.

Djamarah, M.Ag, D. B. (2010). Strategi Belajar Mengajar . Jakarta: Rineka Cipta.

Sanjaya, MP.d, P. (2006). Strategi Pembelajaran. Jakarta: Kencana Prenada Media Group. Sugiyono, P. (2012). Metode Penelitian pendidikan. Jakarta: Alfabeta. 